\title{
Analysis of Unstable Regions in Vector-Controlled IPMSM Sensorless Control
}

\author{
Yasuhiro Yamamoto Member (MEIDENSHA CORPORATION) \\ Yoshitaka Higashi Member (MEIDENSHA CORPORATION) \\ Hiroaki Matsuno Member (KOFU MEIDENSHA Electric Mfg. Co., Ltd.) \\ Satoshi Ogasawara Member (HOKKAIDO UNIVERSITY)
}

Keywords: PM motor, IPMSM, stability analysis, magnetic saturation, sensor-less control

To promote energy saving, permanent magnet field synchronous motors (PMSM) of high efficiency are used also in industrial applications in recent years. We have also been studying sensorless control that uses a magnetic flux observer of the same dimension.

However, our conducted experiment revealed that some motors are likely to step out even at a light load. We could not improve this abnormal phenomenon after trying all different adjustments of feedback gain to the magnetic flux observer. Assuming there should have been some other causes therefore, we continued the study using a PMSM ( $37 \mathrm{~kW}, 6$ poles, $3400 \mathrm{rpm}$ ) of IPM type, having a crosssectional shape shown in Fig. 1.

This motor has a characteristic that magnetic saturation is likely to arise because it is designed to have smaller outside dimensions of stator iron core. In addition, motors of IPM type have a large exciting inductance, and therefore the armature reaction magnetic flux is also large. From those features, we assumed that magnetic saturation had some relation to the unstable phenomenon.

Hence, we first used the finite element method (FEM) to analyze the magnetic properties of the motor. The analysis conditions were set by combining two types of current components, one on a field magnet axis (d-axis) of armature current and the other on an axis (q-axis) orthogonal to the former, and we calculated the winding linkage magnetic flux and the terminal voltage under each condition.

Next, we calculated how the assumed characteristics of the magnetic flux of the magnetic flux observer would change based on the current conditions, which were set for the FEM analysis, and the terminal voltage resulting from the analysis. While the inductance of the observer model keeps at a constant value, the motor inductance changes when the load varies affected by the magnetic saturation. As a result, the assumed error of the magnetic flux also changes by the load conditions. We examined the phase error characteristics due to that effect using the result of FEM analysis. The results of calculation of assumed phase error are expressed as contours on the current coordinates of d-axis and q-axis, making the characteristics apparent in Fig. 3. The diagram indicated that the phase error

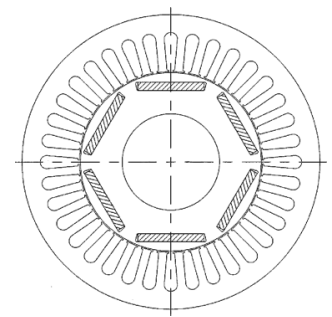

Fig. 1. Cross-sectional view of motor becomes negative in the region in which the q-axis current increases, causing magnetic saturation.

From the result of this analysis, we assumed that a step-out phenomenon would take place by the principle as described below. Let us suppose a case in which the load on the motor increases and the current vector has reached the region of negative phase errors like the position of arrow in Fig. 3. The sensorless control issues a current command vector on the basis of this assumed phase. The current command, however, starts to move further in the negative direction from the present phase because the assumed phase error is negative. At this moment, the actual current also moves in the negative direction, and a far larger negative assumed phase error would result. In other words, positive feedback is made up of the assumed phase error and the current of the magnetic flux observer, the current vector is accelerated to the negative phase direction such as the arrow in Fig. 3, and finally, a step-out phenomenon takes place, which is the mechanism of step out.

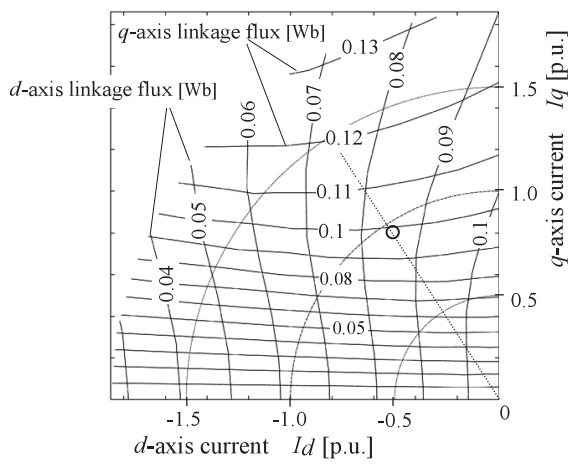

Fig. 2. Characteristics of magnetic flux distribution by FEM analysis

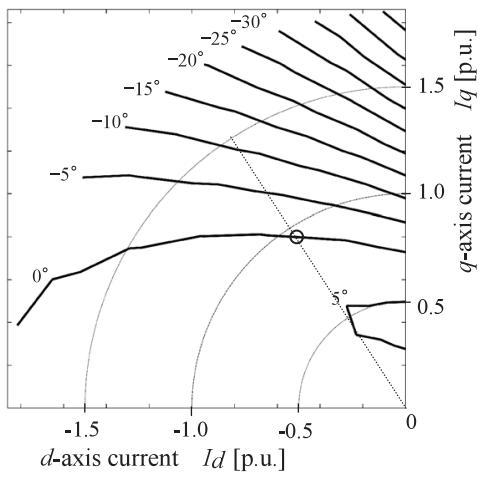

Fig. 3. Characteristics of assumed phase errors 


\title{
ベクトル制御形IPMSM センサレス制御の不安定領域の解析
}

\author{
正員 山本 康弘* 正員東 義高* \\ 正員 松野 浩晃 ${ }^{* *}$ 正 員 小笠原悟司 ${ }^{* * *}$
}

\section{Analysis of Unstable Regions in Vector-Controlled IPMSM Sensorless Control}

Yasuhiro Yamamoto*, Member, Yoshitaka Higashi*, Member, Hiroaki Matsuno**, Member, Satoshi Ogasawara***, Member

This paper reports our study of a phenomenon in which magnetic saturation causes a step-out in sensorless control of IPMSM motors using the magnetic flux observer. The Finite-Element-Method (FEM) can simulate the flux distribution and electromotive force at any armature current. The obtained voltage is supplied to the flux observer containing model errors. Under stable condition, the estimated phase error of this observer is calculated by easy vector operational expression. By the phase error characteristics, it was found that the unstable current appeared in the region, where the error fluctuation increases to the negative direction. We described this problem was caused by the voltage equivalent to interference component arising from the phase error fluctuation. Finally, we suggested a method of avoiding this unstable phenomenon and showed the improved result obtained through some experiments.

キーワード : PM モータ, IPMSM, 安定解析, 磁気飽和, センサレス制御

Keywords: PM motor, IPMSM, stability analysis, magnetic saturation, sensor-less control

\section{1. まえがき}

近年，永久磁石が高性能化したことにより，永久磁石界磁 形同期電動機 (PMSM) が小形サーボモータの主流になっ ている。このPMSMは，誘導機に比べて二次導体の損失 が存在しないため高効率および小形化できるという特徵が ある。これに着目して産業用の省エネルギー用途にも適用 されるようになった。一般産業用は動力源が主用途である ため, 高い応答性能よりも耐環境性やメンテナンス性を重 視して位置センサレス制御を適用している。

この位置センサレス制御方式には様々な方法が報告され ている ${ }^{(1) \sim(4)}$ 。そのひとつに同一次元磁束オブザーバを用い た位置センサレス制御方式がある ${ }^{(1)}$ 。筆者らも，この方式に 積分の高次離散近似やゲイン設定方法を改良して，240 Hz 程度の高い周波数まで適用できる方法を研究してきた ${ }^{(5)}$ 。

\footnotetext{
* (株) 明電舎

₹ 410-8588 沼津市東間門字上中溝 515 番地 MEIDENSHA CORPORATION

515, Kaminakamizo, Higashimakado, Numazu 410-8588

** (株) 甲府明電舎

于 409-3894 中央市中楯 825

KOFU MEIDENSHA Electric Mfg. Co., Ltd.

825, Nakadate, Cyuo 409-3894

*** 北海道大学

于 060-0814 札暒市北区北 14 条西 9 丁目

HOKKAIDO UNIVERSITY

Kita 14, Nishi 9, Kita-ku, Sapporo 610-0814
}

また，一般産業用には磁石を界磁鉄心内部に組み込んだ 磁石埋込形同期電動機（IPMSM）が多く使用されている。 これは, 磁石を表面に貼り付ける構造と比較して接着工程 が簡単であるため安価に製造できること，また磁極の初期 位置同定や低速運転時に突極性を利用した制御が適用でき るという特長がある。

しかし, 文献 (5) の制御法を IPMSM に適用したところ, 負 荷が増加していくと突然脱調する現象が発生した。当初, 磁 束オブザーバのゲイン設定が原因と考え調整を行ったが, 磁 束応答を不安定現象の振動周波数よりも十分に高速な $5 \mathrm{~ms}$ 程度まで変化させたが, 脱調現象を防止することができず, 最終的にはモデルインダクタンスの設定を小さく変更する しか方法がなかった。このようなセンサレス制御のモデル 設定に起因する脱調メカニズムを解析した報告は少ない。 類似の文献としては, リラクタンスモータを対象として, 磁束オブザーバのモデルインダクタンス設定と安定限界の 関係について実験により調査した報告がある ${ }^{(6)}$ 。最近では, モデルインダクタンス設定と推定位相誤差の関係を解析式 として導出した報告もある(7)。しかし，これら以外にはま だ詳細な報告は見当たらない。そこで本論文では，磁気飽 和によりモータの実インダクタンスが大幅に変化すること に着目し, 磁束オブザーバに設定したモデルインダクタン スと実インダクタンスの誤差により推定位相誤差が生じ, さらにこの位相誤差により制御系が不安定になることを説 明する。 
まず, 最初に磁気飽和を考慮した有限要素法 (FEM) 解 析を行い, 電機子反作用電流と磁極軸 $(d$ 軸) や直交軸 $(q$ 軸）の巻線鎖交磁束を計算しておく。以降はこの FEM 解 析結果を用いて分析を行っている。また，電流と磁束およ び定格速度から端子電圧や発生トルクを計算し,さらに, 定常状態に限定して磁束オブザーバの推定位相の誤差成分 を求めた。その結果, 負荷が増加して $q$ 軸電流が大きくな るにつれて磁気飽和が強くなり $q$ 軸インダクタンスが減少 すること, また $q$ 軸電流の増加と共に磁極推定の位相誤差 も正から負に変化し，その変化率も急激に増大することを 示す。

次に，このような電流によって位相誤差特性が変動する 磁束オブザーバを用いてセンサレスベクトル制御を構成し た場合について，定常的および過渡的な $2 つ 0$ 観点から安 定性を検討する。定常的には位相誤差によって電流制御の 軸ズレがどのような点に収束するかを調べ，推定位相䛊差 が負になる領域では収束条件が得られないことを示す。ま た過渡的には，位相誤差の変化項が電流制御系にどのよう な影響を与えるかを検討し, 軸間の干渉電圧と同様な外乱成 分が発生するため制御系が振動的になりやすいことを示す。

最後に，この不安定現象の対策方法について述べ，実機 試験による安定限界の計測を行って改善法の効果を確認し ている。

\section{2. モータの FEM 解析}

今回は Table 1 の定格および Fig. 1 の断面形状の IPMSM を検討対象モデルとし，これに FEM 解析を適用した。

〈2・1〉IPMSM の特徵 IPMSM は誘導機と異なり二 次導体の損失が発生せず，電機子巻線の銅損と電機子鉄心 の鉄損が主な発熱源となる。このうちモー夕外周の継鉄部 で発生する鉄損は，これに接している外周の冷却フィンで 放熱されるため巻線の温度上昇への影響が比較的少ない。 この特性を利用して, 継鉄部の鉄心を極限まで削減し, そ

Table 1. Motor ratings and constants.

\begin{tabular}{l|c}
\hline \multicolumn{2}{c}{ Motor Ratings } \\
\hline Power & $37 \mathrm{~kW}$ \\
\hline Pole & 6 pole \\
\hline Speed & $3400 \mathrm{~min}^{-1}$ \\
\hline Voltage & $170 \mathrm{~V}$ \\
\hline Current & $145 \mathrm{~A}$ \\
\hline
\end{tabular}

\begin{tabular}{c|c}
\hline \multicolumn{2}{c}{ Motor constants } \\
\hline$R_{1}$ & $7.0 \mathrm{~m} \Omega$ \\
\hline \multirow{2}{*}{$L_{d}$} & $\begin{array}{c}0.20 \mathrm{mH} \\
(0.31 \text { p.u. })\end{array}$ \\
\hline \multirow{2}{*}{$L q$} & $\begin{array}{c}0.60 \mathrm{mH} \\
(0.95 \text { p.u. })\end{array}$ \\
\hline
\end{tabular}

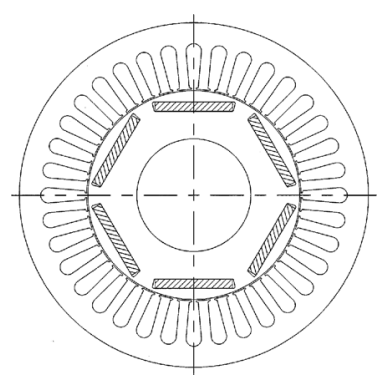

Fig. 1. Cross-sectional view of motor.
の分だけ巻線スロット面積を大きく取り銅損を減少すれば 小形なモー夕を設計できる。しかし，この設計手法を突き 詰めていくと磁気飽和が発生しやすくなり，センサレス制 御時のモデル誤差が大きくなる。

さらに都合の悪いことには, IPMSM は電機子反作用磁束 が大きいという問題がある。誘導機のベクトル制御の場合 には漏れインダクタンスの磁束成分しか増磁しないが, 同 期機の場合には電機子反作用磁束分の増磁が発生する。今 回解析するモータでは $q$ 軸インダクタンスは $L_{q}=0.95$ p.u. という大きな值であり, 誘導機に比べ負荷電流による増磁 量が格段に大きく磁気飽和が発生しやすい。そのため, 磁 気飽和特性などモータの設計内容を十分把握した上でセン サレス制御を適用する必要がある。

$\langle 2 \cdot 2\rangle$ FEM 解析の特徵 Fig. 1 のような構造の IPMSM について, モデル誤差要因である磁気飽和特性を調 べるために FEM 解析を行った。下記に今回使用した FEM の特徴を簡単に述べる。

（1） FEM 解析の種類 FEM 解析は磁気非線形を考 慮した二次元場の静磁界解析を使用した。境界条件として 電機子電流を設定して磁束分布を計算し, $d$ 軸と $q$ 軸の巻 線位置より各軸の巻線鎖交磁束を求めている。

（2）スロット高調波の除去ここの巻線鎖交磁束から 巻線スロットと磁極の相対位置による脈動成分を除去する ため, 回転子を少しずつ回転させながら一極対分について 計算し，この結果から時間高調波を含まない基本波成分の 鎖交磁束を抽出している。

（3）電機子電流の設定 FEM 解析の境界条件として 設定した電機子電流には, 弱め界磁電流とトルク電流の 2 軸の成分が存在する。そこで, 電機子電流の振幅と位相を 組み合わせた複数の条件を設定して計算した。振幅成分に ついては 1.8 p.u. までを等間隔に 9 分割し，また位相成分 については $(\pi / 2 \sim \pi)$ 間の位相進み領域を 9 分割している。 つまり, $d$ 軸電流は実用域である弱め界磁領域 $\left(I_{d}<0\right)$ の みに限定し, $q$ 軸電流についても対称性を考慮して力行領 域 $(I q>0)$ を解析対象としている。

$\langle\mathbf{2} \cdot \mathbf{3}\rangle$ FEM 解析結果 $\langle 2 \cdot 2\rangle$ 節のような複数の $d$ 軸 や $q$ 軸電流を設定して FEM 解析を計算し, それぞれにおい て $d$ 軸と $q$ 軸の巻線鎖交磁束を求めた。そして, これらの 結果をまとめて表現するため, $d$ 軸と $q$ 軸の鎖交磁束を $d-q$ 電流座標の等高線として描いたものがFig. 2 である。ここ で電流軸は定格值を基準とする単位法に設定した。また， 参考として定格トルク発生条件の電流を示す○印と, その 位相を示す補助線および 0.5 p.u. 間隔の電流振幅を示す補 助円を記入している。この Fig. 2 から次のようなモー夕特 性が判明した。

（1）磁気飽和とインダクタンスの変化縦の等高線 は $d$ 軸鎖交磁束を, 横の等高線は $q$ 軸鎖交磁束を示してい る。理論どおり $q$ 軸磁束は $I_{q}=0$ のときに零になる。 $d$ 軸 磁束は $I_{d}=0$ では永久磁石の残留磁束分が発生し, 弱め 界磁電流 $\left(I_{d}<0\right)$ の増加にともない $d$ 軸磁束が減少して 
いる。

$q$ 軸電流が定格点より大きな領域では, $q$ 軸磁束の等高 線間隔が急に広くなっていることが分かる。これは，磁気 飽和の影響によって定格付近から急激にインダクタンスが 減少していることを示している。

(2) $d-q$ 軸間の相互インダクタンス 本来, $d$ 軸拉よ び $q$ 軸磁束の等高線は各軸に直交した直線になるはずであ るが，解析結果にはゆがみが発生している。これはロー夕 外周と磁石を挿入するスロット間の細長い鉄心部において, 永久磁石の磁束と $q$ 軸電機子反作用磁束が合成されると非 対称な磁気飽和になり, その結果 $d-q$ 軸間の相互インダク タンス成分が発生したことを示している。

（3）端子電圧と卜ルク特性 Fig. 2 の鎖交磁束特性 と定格速度から各軸の速度起電力を計算して合成すれば端 子電圧が，また鎖交磁束と電機子電流の外積から発生卜ル クが計算できる。これらを Fig. 2 と同様に $d-q$ 電流座標上 の等高線で表したものが Fig. 3 である。非線形を考慮しな い理想的な場合には電圧の等高線は棈円状に，またトルク の等高線は双曲線状になるはずである。しかし, Fig. 3 では 電圧成分の等高線が定格電圧以上になると急に間隔が広く なっており，このことからも磁気飽和の影響が確認できる。

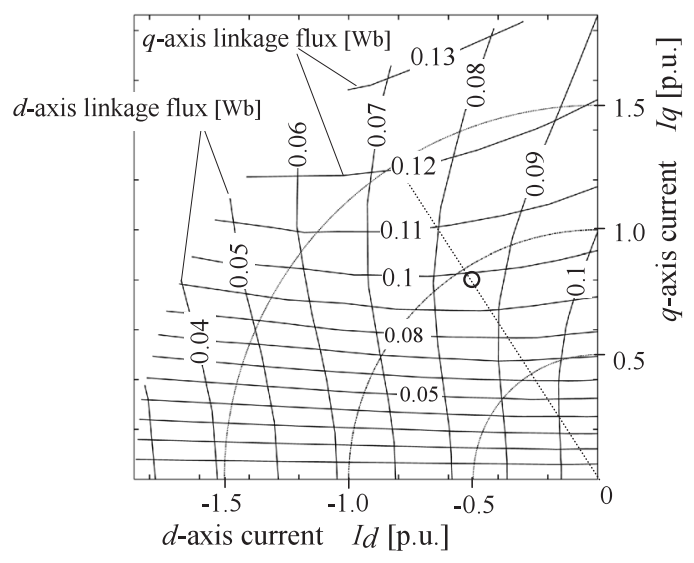

Fig. 2. Characteristics of magnetic flux distribution by FEM analysis.

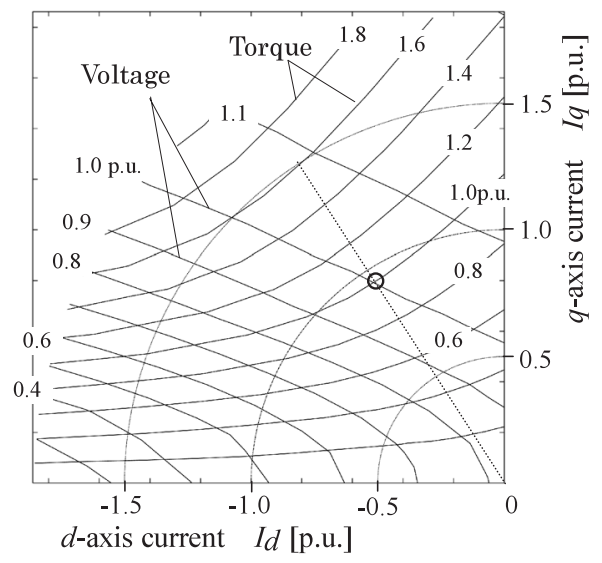

Fig. 3. Contour line of voltage and torque.

\section{3. 磁束オブザーバの磁極推定位相誤差}

最初に磁束オブザーバ単体のオープンループ特性につい て調べるため, Fig. 4 のようなセンサ付とセンサレスの切 り替えスイッチ SW1 を付加した電流制御モードのベクト ル制御系を想定する。

このスイッチ SW1を（enc）側に設定し，センサ付の電 流制御モードでベクトル制御を構成した場合について考え る。このときは磁束オブザーバが出力する推定位相 $\hat{\theta}$ を制 御の座標変換に使用していないため，オブザーバ単体の磁 極推定位相誤差 $\Delta \theta$ の特性を調べることができる。突極機 であっても拡張誘起電圧の概念を適用すれば(4), 磁束オブ ザーバに非突極モデルを使用しても磁極位相を推定するこ とが可能であるので， $\left(L^{*}=L_{d}^{*}=L_{q}^{*}\right)$ のように $d$ 軸と $q$ 軸 のオブザーバモデルインダクタンスを等しい值に設定した。

Fig. 5 のベクトル図は FEM 解析に設定した電機子電流 $I_{1}$ と結果の端子電圧 $E_{1}$ の例を $d-q$ 座標上で示したものであ る。周波数が高いため巻線抵抗の影響を無視すると，(1)式 のように端子電圧 $\boldsymbol{E}_{1}=\omega \cdot\left\{-\phi_{q}+j \phi_{d}\right)$ から電機子反作用 による電圧降下成分 $j \omega L^{*} I_{1}$ を減算すれば，定常時の拡張誘 起電圧 $\hat{\boldsymbol{E}}_{0}$ を計算できる。磁束オブザーバはこの拡張誘起 電圧 $\hat{\boldsymbol{E}}_{0}$ から $90^{\circ}$ 遅れた位相を磁極推定軸として出力する ので, 磁極推定位相誤差 $\Delta \theta$ はこのべクトル $\hat{\boldsymbol{E}}_{0}$ と $q$ 軸との

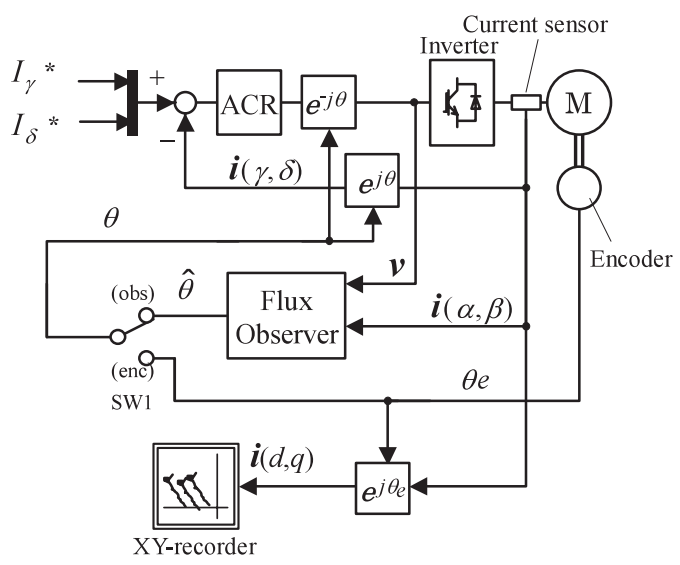

Fig. 4. Block diagram of an analysis model.

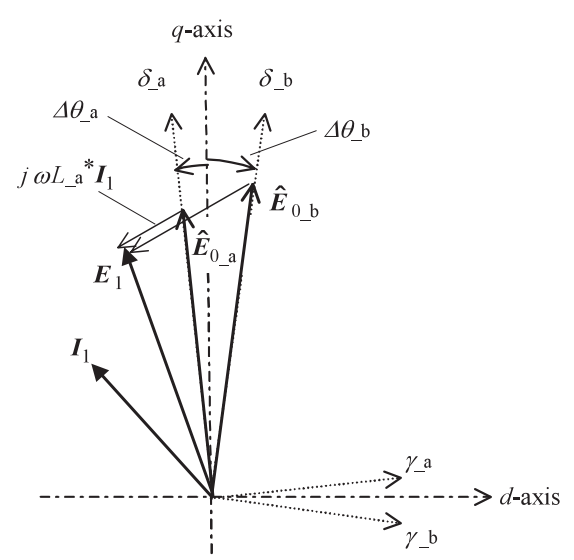

Fig. 5. Phase error of current vector. 


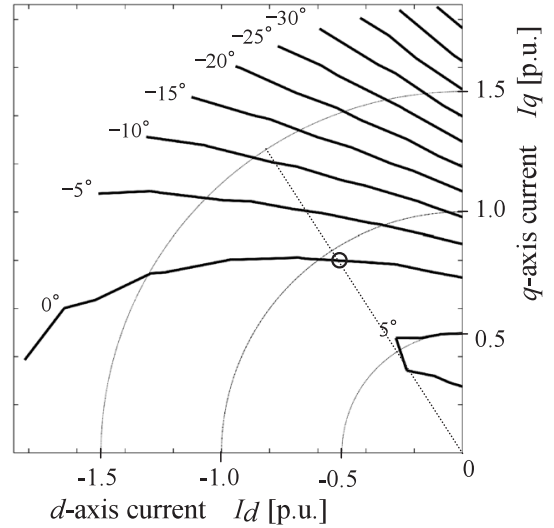

Fig. 6. Phase error distribution using rated model inductance $\left(L^{*}=0.60 \mathrm{mH}\right)$.

位相差に等しく，(2) 式により計算することができる。

$$
\begin{aligned}
& \hat{\boldsymbol{E}}_{0}=\hat{E}_{0 d}+j \hat{E}_{0 q} \\
&=\omega \cdot\left\{-\left(\phi_{q}-L^{*} \cdot I_{q}\right)+j\left(\phi_{d}-L^{*} \cdot I_{d}\right)\right\} \cdots \cdots \cdots \\
& \Delta \theta=\tan ^{-1}\left(-\hat{E}_{0 d} / \hat{E}_{0 q}\right) \cdots \cdots \cdots \cdots \cdots \cdots \cdots \cdots \cdots \cdots \cdots \\
& \text { ここに, } L^{*}: \text { モデルのインダクタンス, } \phi_{d}, \phi_{q}:
\end{aligned}
$$

FEM 解析結果の $d$ 軸と $q$ 軸鎖交磁束, $\omega$ : 定格角 周波数, $\hat{E}_{0 d}, \hat{E}_{0 q}$ : モデルの永久磁石による起電 力, $\Delta \theta:$ オブザーバの磁極推定位相誤差

〈2・2〉節で設定した各電流設定条件において，この磁極 推定位相誤差 $\Delta \theta$ を計算した。ここで，モデルのインダク タンス $L^{*}$ は Fig. 2 の定格トルク点における $q$ 軸磁束から計 算した $L_{q}=0.60 \mathrm{mH}$ の值を設定している。Fig. 2 の鎖交磁 束分布で示すようにモータのインダクタンスは変動してお り, 実機のインダクタンス $L_{q}$ に対してモデルインダクタン ス $L^{*}$ の方が小さい場合には, Fig. 5 の $\hat{\boldsymbol{E}}_{0 \Omega}$ のように推定位 相誤差 $\Delta \theta_{a}$ は正值となる。逆にモデルインダクタンス $L^{*}$ の方が大きな場合には推定位相誤差は $\Delta \theta_{b}$ のように負值と なる。この位相誤差 $\Delta \theta$ の分布についても $d-q$ 電流座標上 に㧍ける等高線として表したものが Fig. 6 である。 $\Delta \theta=0^{\circ}$ の等高線はちょうど $L^{*}=L_{q}$ の条件であり，これよりも $q$ 軸電流振幅が大きくなる方向に $\Delta \theta$ が負值となる領域が存 在している。また，その位相誤差の変化量も， $q$ 軸電流振 幅が大きくなるほど急激に变化していることが判明した。

\section{4. 脱調現象の原因推定と対策方法}

$\langle 4 \cdot 1\rangle$ 位相誤差の収束特性 次に, Fig. 4 の SW1 を オブザーバ推定位相側（obs）に切り替えて，七ンサレスベ クトル制御系を構成した場合を考える。磁束オブザーバは Fig. 6 のような磁極推定位相誤差 $\Delta \theta$ の特性を有しているの で, 逆に考えると電流制御の基準である $\gamma-\delta$ 軸の電流指令 $\left(I_{\gamma}^{*}, I_{\delta}^{*}\right)$ が与えられても, 実電流 $I_{d}, I_{q}$ は (3) 式で示される ように $\Delta \theta$ だけずれた電流べクトルに収束しているはずで ある。

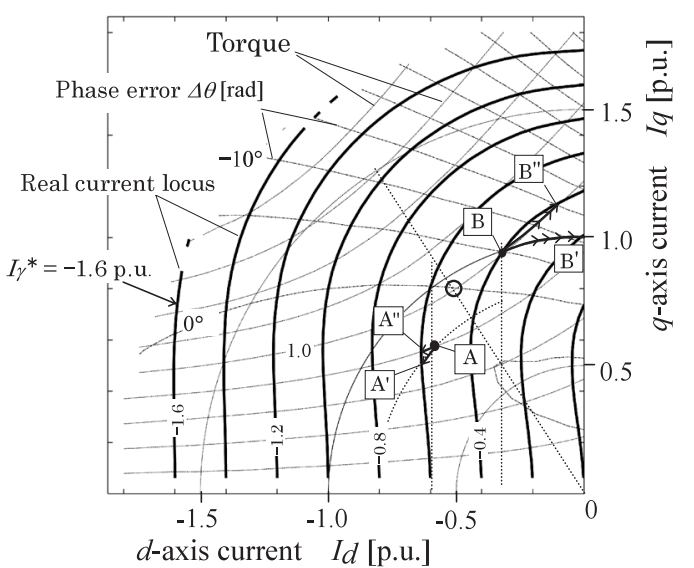

Fig. 7. Distortion of the current locus at rated model inductance $\left(L^{*}=0.60 \mathrm{mH}\right)$.

$\left[\begin{array}{l}I_{d} \\ I_{q}\end{array}\right]=\left[\begin{array}{cc}\cos \Delta \theta & -\sin \Delta \theta \\ \sin \Delta \theta & \cos \Delta \theta\end{array}\right]\left[\begin{array}{l}I_{\gamma}^{*} \\ I_{\delta}^{*}\end{array}\right]$

ここに, $I_{\gamma}^{*}: \gamma$ 軸電流指令, $I_{\delta}^{*}: \delta$ 軸電流指令

そこで, 電流指令 $\left(I_{\gamma}^{*}, I_{\delta}^{*}\right)$ の各点に対応した実電流 $\left(I_{d}, I_{q}\right)$ を計算し，その結果から $I_{\gamma}^{*}$ 指令が一定条件の実電流の軌跡 を描くと Fig.7の太線のような特性となる。また, Fig. 7で は後述の説明のために, Fig. 6 の位相誤差成分や Fig. 3 の トルクの等高線も細線で示している。

$I_{\gamma}^{*}$ を一定に設定してセンサレス制御を行っても，電流制 御モードと速度制御モードによって, 次のように実電流べ クトルの収束点に違いがある。

（1）電流制御モードにおける収束点 電流制御モー ドでは， $\left(I_{\gamma}^{*}, I_{\delta}^{*}\right)$ 指令が一定であるため実電流のベクトルも 常に半径が一定の円軌跡上に存在する。例えば $I_{\gamma}^{*}=0.6$ p.u. を考えると, 本来は Fig. 7 の 点で示すように $I_{d}=0.6$ p.u. の軸上に存在するはずである。しかし，推定位相誤差 $\Delta \theta$ が 正の領域であるため実電流は円軌跡上を正の位相方向に移 動し, 実電流べクトル軌跡との交点 $\mathrm{A}^{\prime}$ に収束する。これ に対して，位相誤差が負の領域では, B 点から $\mathrm{B}^{\prime}$ のように 実電流が円軌跡上を負の位相方向に移動する。ところが実 電流軌跡との交点が存在しないため, 実電流は遅れ方向に 移動し続け収束しない。

（2）速度制御モードに扔ける収束点速度制御系の 場合には，速度フィードバック制御によって負荷トルクに 釣り合うように $I_{\delta}^{*}$ 電流指令が増減する。そのため, Fig.7 の $\mathrm{A}$ 点から, 今度は実電流がトルクの等高線に沿って正の 位相方向に移動し， A" の記号で示すような負荷トルクと 発生トルクが一致する点に収束する。位相誤差が正から負 の領域に移動すると B 点のようにトルクの等高線に沿って 負の位相方向に移動して， $\mathrm{B}^{\prime \prime}$ 点のように離れた点に収束 する。

このように制御モードにより収束点は異なっているが, どちらの場合でも推定位相誤差が正の領域では安定な収束 点が存在することが分かった。しかし位相誤差が負の領域 


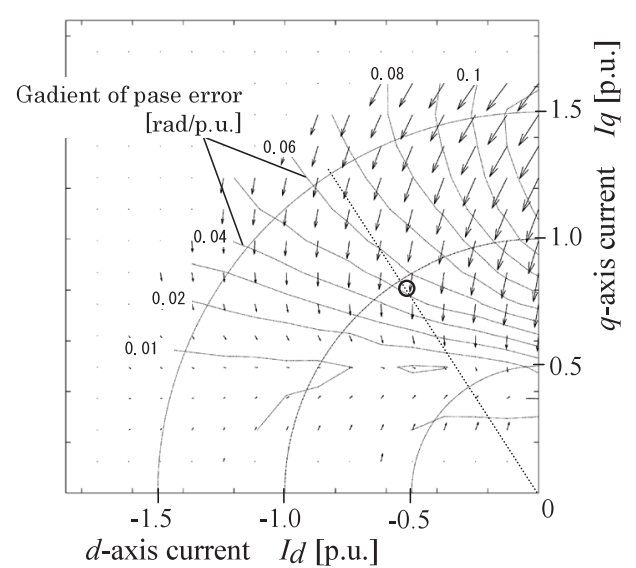

Fig. 8. Gradient of phase error $\left(L^{*}=0.60 \mathrm{mH}\right)$.

に入ると，安定な収束点が存在しないか，または収束点が 離れた点に急に移動するため脱調現象が生じるものと考え られる。

\section{$\langle\mathbf{4} \cdot \mathbf{2}\rangle$ 位相誤差の変化による電流制御系の干渉成分}

前節では定常時の収束性を検討したが，本節では位相誤 差が変動することに起因する不安定要因について検討する。

Fig. 8 は Fig. 6 の位相䛊差をポテンシャルとみなし (4) 式 により傾きベクトルを計算したものである。そのベクトル の方向と大きさを矢印で示し，また，大きさを等高線とし て示している。この結果から， $q$ 軸電流が大きくなると位 相誤差の変化量も大きいことが分かる。

$$
\operatorname{grad}\left\{\Delta \theta\left(I_{d}, I_{q}\right)\right\}=\frac{\partial \Delta \theta\left(I_{d}, I_{q}\right)}{\partial I_{d}} \cdot \boldsymbol{d}+\frac{\partial \Delta \theta\left(I_{d}, I_{q}\right)}{\partial I_{q}} \cdot \boldsymbol{q}
$$

ここで, $\Delta \theta\left(I_{d}, I_{q}\right): d-q$ 電流発生時の推定位相誤

差, $d: d$ 軸単位ベクトル, $\boldsymbol{q}: q$ 軸単位ベクトル

次に，推定位相誤差が変化した場合に，電流制御系にど のような影響を与えるかを検討する。実際には，磁束オブ ザーバの位相推定遅れやインダクタンス変動などの複雑な 要素が存在するが，ここでは問題を簡単にするため推定位 相誤差の変動による成分のみに限定する。そしてその影響 を電圧電流方程式の外乱成分に近似することにより，振動 現象の物理的な意味を明らかにする。

本節では, 磁束オブザーバの推定位相 $\hat{\theta}$ (5) 式のよう に定常成分 $\hat{\theta}_{0}$ と微小变化成分 $\Delta \theta^{\prime}$ に分離して取り扱う。

$$
\hat{\theta}=\hat{\theta}_{0}+\Delta \theta^{\prime}
$$

推定位相の微小变化 $\Delta \theta^{\prime}$ による影響は, Fig. 4 の $\boldsymbol{e}^{j \theta}$ と $\boldsymbol{e}^{-j \theta}$ の二力所の回転座標変換部で発生する。

電流検出成分を固定座標系 $(\alpha-\beta$ 軸) から制御座標系 $(\gamma-\delta$ 軸）に変換する $\boldsymbol{e}^{j \theta}$ 部分では，定常成分は (6) 式の変換式で 示される。

$$
\left[\begin{array}{c}
I_{\gamma 0} \\
I_{\delta 0}
\end{array}\right]=\left[\begin{array}{cc}
\cos \hat{\theta}_{0} & \sin \hat{\theta}_{0} \\
-\sin \hat{\theta}_{0} & \cos \hat{\theta}_{0}
\end{array}\right]\left[\begin{array}{c}
I_{\alpha 0} \\
I_{\beta 0}
\end{array}\right]
$$

\section{ここに, $I_{\gamma 0}, I_{\delta 0}: \gamma-\delta$ 軸電流の定常成分}

この状態から，電流は一定のままで $\Delta \theta^{\prime}$ の微小変化だけ が発生したと仮定すると, (7) 式のように座標変換後の検出 電流成分の中に $\Delta I_{\gamma}, \Delta I_{\delta}$ の微小変化成分が生じる。

$$
\begin{aligned}
& {\left[\begin{array}{l}
I_{\gamma 0}+\Delta I_{\gamma} \\
I_{\delta 0}+\Delta I_{\delta}
\end{array}\right]} \\
& =\left[\begin{array}{cc}
\cos \left(\hat{\theta}_{0}+\Delta \theta^{\prime}\right) & \sin \left(\hat{\theta}_{0}+\Delta \theta^{\prime}\right) \\
-\sin \left(\hat{\theta}_{0}+\Delta \theta^{\prime}\right) & \cos \left(\hat{\theta}_{0}+\Delta \theta^{\prime}\right)
\end{array}\right]\left[\begin{array}{c}
I_{\alpha 0} \\
I_{\beta 0}
\end{array}\right] \\
& =\left\{\left[\begin{array}{cc}
\cos \hat{\theta}_{0} & \sin \hat{\theta}_{0} \\
-\sin \hat{\theta}_{0} & \cos \hat{\theta}_{0}
\end{array}\right]+\Delta \theta^{\prime} \cdot\left[\begin{array}{cc}
\sin \hat{\theta}_{0} & -\cos \hat{\theta}_{0} \\
\cos \hat{\theta}_{0} & \sin \hat{\theta}_{0}
\end{array}\right]\right\}\left[\begin{array}{c}
I_{\alpha 0} \\
I_{\beta 0}
\end{array}\right] \\
& =\left\{\left[\begin{array}{ll}
1 & 0 \\
0 & 1
\end{array}\right]+\Delta \theta^{\prime} \cdot\left[\begin{array}{cc}
0 & 1 \\
-1 & 0
\end{array}\right]\right\}\left[\begin{array}{cc}
\cos \hat{\theta}_{0} & \sin \hat{\theta}_{0} \\
-\sin \hat{\theta}_{0} & \cos \hat{\theta}_{0}
\end{array}\right]\left[\begin{array}{l}
I_{\alpha 0} \\
I_{\beta 0}
\end{array}\right]
\end{aligned}
$$

(7) 式では三角関数を展開し, $\Delta \theta^{\prime} \ll \pi$ とみなして $\cos \left(\Delta \theta^{\prime}\right) \fallingdotseq 1$ 㧍よび $\sin \left(\Delta \theta^{\prime}\right) \fallingdotseq \Delta \theta^{\prime}$ の近似を適用してい る。これから, 変化項のみを抽出するため (6) 式の定常成 分を減算し, さらに右辺の変数を(6) 式で置換すれば (8) 式 のような $\gamma-\delta$ 軸の電流変化成分に近似できる。

$$
\left[\begin{array}{l}
\Delta I_{\gamma} \\
\Delta I_{\delta}
\end{array}\right]=-\Delta \theta^{\prime} \cdot\left[\begin{array}{cc}
0 & -1 \\
1 & 0
\end{array}\right]\left[\begin{array}{l}
I_{\gamma 0} \\
I_{\delta 0}
\end{array}\right] \cdots
$$

次に, 出力電圧の座標変換部 $\boldsymbol{e}^{-j \theta}$ についても, 同様に (9) 式の定常成分の座標変換式から $\Delta \theta^{\prime}$ の影響により生じる電 圧指令の変化成分 $\Delta V_{\alpha}, \Delta V_{\beta}$ を求めたものが (10) 式であ る。ここで右辺の電圧成分は, 電流制御系の比例ゲイン $K_{p c}$ と (8) 式の電流検出誤差による電圧成分も含んでいる。

$$
\begin{aligned}
& {\left[\begin{array}{c}
V_{\alpha 0} \\
V_{\beta 0}
\end{array}\right]=\left[\begin{array}{cc}
\cos \hat{\theta}_{0} & -\sin \hat{\theta}_{0} \\
\sin \hat{\theta}_{0} & \cos \hat{\theta}_{0}
\end{array}\right]\left[\begin{array}{c}
V_{\gamma 0} \\
V_{\delta 0}
\end{array}\right] \ldots \ldots \ldots \ldots \ldots . } \\
& {\left[\begin{array}{c}
V_{\alpha 0}+\Delta V_{\alpha} \\
V_{\beta 0}+\Delta V_{\beta}
\end{array}\right]=} {\left[\begin{array}{cc}
\cos \left(\hat{\theta}_{0}+\Delta \theta^{\prime}\right) & -\sin \left(\hat{\theta}_{0}+\Delta \theta^{\prime}\right) \\
\sin \left(\hat{\theta}_{0}+\Delta \theta^{\prime}\right) & \cos \left(\hat{\theta}_{0}+\Delta \theta^{\prime}\right)
\end{array}\right] } \\
& \times\left\{\left[\begin{array}{c}
V_{\gamma 0} \\
V_{\delta 0}
\end{array}\right]-K_{p c}\left[\begin{array}{c}
\Delta I_{\gamma} \\
\Delta I_{\delta}
\end{array}\right]\right\}
\end{aligned}
$$

(10) 式の回転座標部分に前述と同様な近似を適用すれば (11) 式のように近似でき, さらに微小変化項どうしの積を 無視すれば(10) 式は (12) 式のように変換できる。

$$
\begin{aligned}
& {\left[\begin{array}{cc}
\cos \left(\hat{\theta}_{0}+\Delta \theta^{\prime}\right) & -\sin \left(\hat{\theta}_{0}+\Delta \theta^{\prime}\right) \\
\sin \left(\hat{\theta}_{0}+\Delta \theta^{\prime}\right) & \cos \left(\hat{\theta}_{0}+\Delta \theta^{\prime}\right)
\end{array}\right]} \\
& \approx\left[\begin{array}{cc}
\cos \hat{\theta}_{0} & -\sin \hat{\theta}_{0} \\
\sin \hat{\theta}_{0} & \cos \hat{\theta}_{0}
\end{array}\right]\left\{\left[\begin{array}{cc}
1 & 0 \\
0 & 1
\end{array}\right]+\Delta \theta^{\prime}\left[\begin{array}{cc}
0 & -1 \\
1 & 0
\end{array}\right]\right\} \\
& {\left[\begin{array}{c}
V_{\alpha 0}+\Delta V_{\alpha} \\
V_{\beta 0}+\Delta V_{\beta}
\end{array}\right]=\left[\begin{array}{cc}
\cos \hat{\theta}_{0} & -\sin \hat{\theta}_{0} \\
\sin \hat{\theta}_{0} & \cos \hat{\theta}_{0}
\end{array}\right]} \\
& \times\left\{\left[\begin{array}{c}
V_{\gamma 0} \\
V_{\delta 0}
\end{array}\right]+\Delta \theta^{\prime}\left[\begin{array}{cc}
0 & -1 \\
1 & 0
\end{array}\right]\left[\begin{array}{c}
V_{\gamma 0} \\
V_{\delta 0}
\end{array}\right]-K_{p c} \cdot\left[\begin{array}{l}
\Delta I_{\gamma} \\
\Delta I_{\delta}
\end{array}\right]\right\}
\end{aligned}
$$


(12) 式から (9) 式の定常成分を減算すると (13) 式のよう に電圧の変化分である $\Delta V_{\gamma}$ と $\Delta V_{\delta}$ が取り出せる。

$$
\begin{aligned}
{\left[\begin{array}{l}
\Delta V_{\alpha} \\
\Delta V_{\beta}
\end{array}\right]=} & {\left[\begin{array}{cc}
\cos \hat{\theta}_{0} & -\sin \hat{\theta}_{0} \\
\sin \hat{\theta}_{0} & \cos \hat{\theta}_{0}
\end{array}\right] } \\
& \times\left\{\Delta \theta^{\prime}\left[\begin{array}{cc}
0 & -1 \\
1 & 0
\end{array}\right]\left[\begin{array}{c}
V_{\gamma 0} \\
V_{\delta 0}
\end{array}\right]-K_{p c} \cdot\left[\begin{array}{c}
\Delta I_{\gamma} \\
\Delta I_{\delta}
\end{array}\right]\right\}
\end{aligned}
$$

さらに, 両辺の左から座標変換の逆行列を掛けて $\gamma-\delta$ 軸 の電圧変化成分に変換すると (14) 式になる。

$$
\left[\begin{array}{l}
\Delta V_{\gamma} \\
\Delta V_{\delta}
\end{array}\right]=\Delta \theta^{\prime}\left[\begin{array}{cc}
0 & -1 \\
1 & 0
\end{array}\right]\left[\begin{array}{c}
V_{\gamma 0} \\
V_{\delta 0}
\end{array}\right]-K_{p c} \cdot\left[\begin{array}{c}
\Delta I_{\gamma} \\
\Delta I_{\delta}
\end{array}\right] \ldots \ldots \ldots
$$

また右辺の電流成分も (8) 式で置換すると (15) 式のよう な $\gamma-\delta$ 軸の電流と電圧変化成分の関倸式が得られる。

$$
\left[\begin{array}{l}
\Delta V_{\gamma} \\
\Delta V_{\delta}
\end{array}\right]=\Delta \theta^{\prime}\left[\begin{array}{cc}
0 & -1 \\
1 & 0
\end{array}\right]\left[\begin{array}{l}
V_{\gamma 0} \\
V_{\delta 0}
\end{array}\right]+K_{p c} \cdot \Delta \theta^{\prime} \cdot\left[\begin{array}{cc}
0 & -1 \\
1 & 0
\end{array}\right]\left[\begin{array}{c}
I_{\gamma 0} \\
I_{\delta 0}
\end{array}\right]
$$

(15) 式は, 推定位相の微小変化 $\Delta \theta^{\prime} に よ り$, 電圧や電流 の定常成分に直交した外乱電圧 $\left(\Delta V_{\gamma}, \Delta V_{\delta}\right)$ が発生すること を示している。この電圧外乱により振動現象が発生する理 由を明確にするため, 電流制御に使用する $\gamma-\delta$ 座標におけ るモータの電圧電流方程式に (15) 式の電圧変化項を加算す れば(16)式として表すことができる。

$$
\begin{aligned}
{\left[\begin{array}{c}
V_{\gamma} \\
V_{\delta}
\end{array}\right]+} & {\left[\begin{array}{c}
\Delta V_{\gamma} \\
\Delta V_{\delta}
\end{array}\right]=\left[\begin{array}{cc}
R_{1}+p L_{\gamma}^{\prime} & -\omega L_{\delta} \\
\omega L_{\gamma} & R_{1}+p L_{\delta}^{\prime}
\end{array}\right]\left[\begin{array}{c}
I_{\gamma 0} \\
I_{\delta 0}
\end{array}\right]+\left[\begin{array}{c}
-\omega \phi_{\delta} \\
\omega \phi_{\gamma}
\end{array}\right] } \\
{\left[\begin{array}{c}
V_{\gamma} \\
V_{\delta}
\end{array}\right]=} & {\left[\begin{array}{cc}
R_{1}+p L_{\gamma}^{\prime} & -\left(\omega L_{\delta}-\Delta \theta^{\prime} \cdot K_{p c}\right) \\
\left(\omega L_{\gamma}-\Delta \theta^{\prime} \cdot K_{p c}\right) & R_{1}+p L_{\delta}^{\prime}
\end{array}\right]\left[\begin{array}{c}
I_{\gamma 0} \\
I_{\delta 0}
\end{array}\right] } \\
& +\left[\begin{array}{c}
-\left(\omega \phi_{\delta}-\Delta \theta^{\prime} \cdot V_{\delta 0}\right) \\
\left(\omega \phi_{\gamma}-\Delta \theta^{\prime} \cdot V_{\gamma 0}\right)
\end{array}\right] \ldots \ldots \ldots \ldots \ldots \ldots \ldots \ldots
\end{aligned}
$$

(16) 式より, 推定位相誤差の変化分 $\Delta \theta^{\prime}$ によって二種類 の外乱電圧が発生することが分かる。一つは右辺の第二項 内にある出力電圧に比例する項であり，もう一つは第一項 の電流制御ゲイン $K_{p c}$ による項である。これらは $\Delta \theta^{\prime}$ が負 の場合に， $\omega$ による軸間の干渉電圧と等価な成分として作 用する。そのため出力電圧が高いほど，また速度や $K_{p c}$ が 大きいほど等価的に干渉電圧が大きくなり, 系が振動的に なりやすい。最終的には干渉成分の大きさが安定限界を超 えると脱調が発生するものと考えられる。

したがって安定限界の条件として，〈4・1〉節で示した位 相誤差が正の領域であること，また本節で示した位相誤差 の負の変化分が大きくてはならないという二つの要因が存 在することが判明した。

$\langle\mathbf{4} \cdot \mathbf{3}\rangle$ 安定限界の改善方法 前節までに示した不安 定要因の対策方法としては, オブザーバのモデルインダク タンスを小さく設定すればよい。このことは経験により分 かっていたが，その根拠を調べるために，モデルインダク

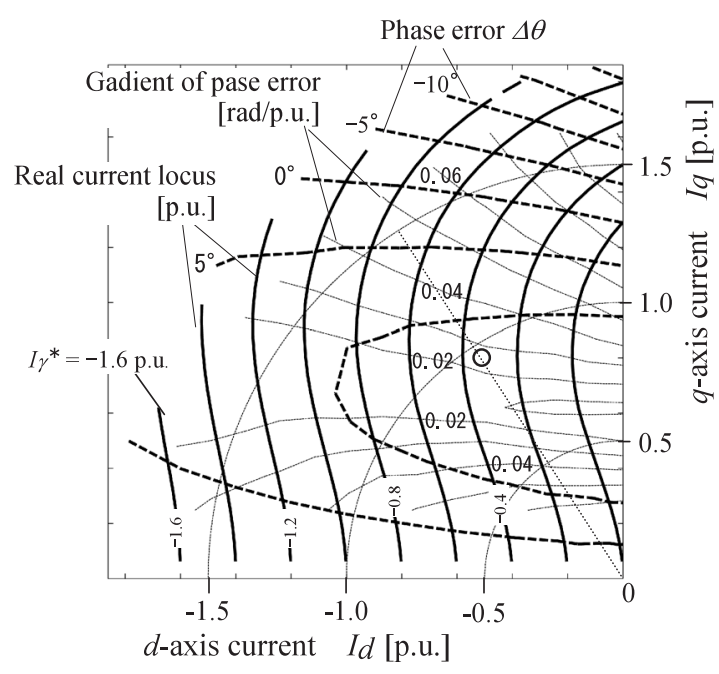

Fig. 9. Phase error and real current characteristics using decreased model inductance $\left(L^{*}=0.43 \mathrm{mH}\right)$.

タンスを定格トルク条件の $q$ 軸インダタンス $L^{*}$ に対し約 $70 \%\left(L^{*}=0.43 \mathrm{mH}\right)$ に減少させて，前節の各成分がどの ように改善されるかを計算した。その結果が Fig.9である。 Fig. 6 に対応する推定位相誤差の等高線を太い点線で, Fig. 7 に対応する位相がずれた実電流の軌跡を太い実線で，そし て Fig. 8 に対応する位相誤差の傾き成分を細線で示してい る。この結果, Fig. 6 に比べ推定位相誤差が正の領域が拡 大し，また，Fig. 8 の位相誤差の傾き成分についても，0.06 の等高線の例を比較するとわかるように，傾きが少ない領 域が拡大している。この結果より，モデルインダクタンス を小さく設定する方法が安定性改善に有効である根拠が解 析的に確認できた。

しかし, 収束した実電流の軌跡はゆがみが大きいため, 無 視できない位相誤差が発生する。これについては電流指令 に位相誤差補償を適用して補正すれば対処可能である。

\section{5. 試験結果による解析結果の検証}

〈5・1〉 試験システム 4 章で考察した要因推定や改善 方法の妥当性を検証するために実機試験を行った。試験シ ステムの構成を Fig. 10 に示す。2 台のセンサ付 IPMSM を 使用し, タイミングベルトで機械的に結合した。負荷モー 夕は位置センサ付ベクトル制御によりトルク制御を行って いる。試験モー夕にも位置センサが取り付けてあるが, セ ンサレス制御には使用せず, 検出電流を正確に $d-q$ 軸成分 に変換するモニ夕用に限定して使用している。

負荷モー夕の速度定格による制限のため， $\omega=50 \%$ と $\omega=75 \%$ 二種類の速度で試験を行った。センサレス方式 は文献(5) で筆者らが提案した固定座標上で構成した同一 次元磁束オブザーバを使用した。また，オブザーバゲイン は各試験速度で安定になるよう微調整している。電流制御 部は $d$ 軸側の応答を約 $1000 \mathrm{rad} / \mathrm{s}\left(K_{p c}=0.29\right.$ p.u. $)$ に設定 し, 非干渉補償はパラメータ変動が大きいため適用してい ない。 


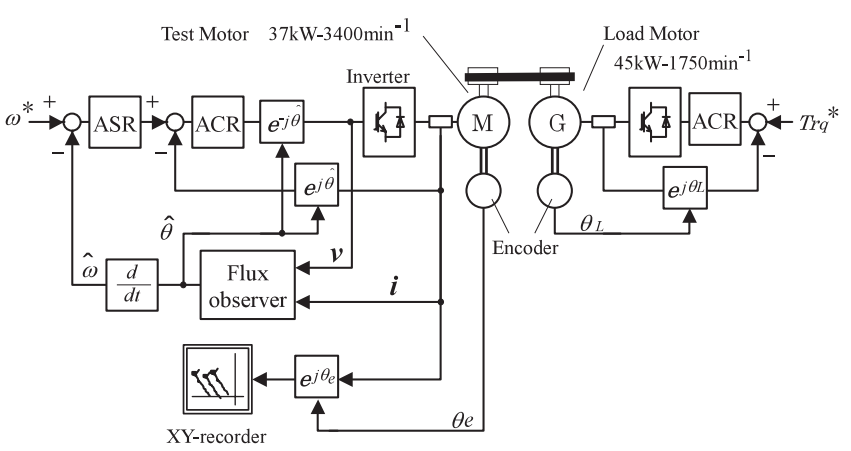

Fig. 10. Experimental system for load test.

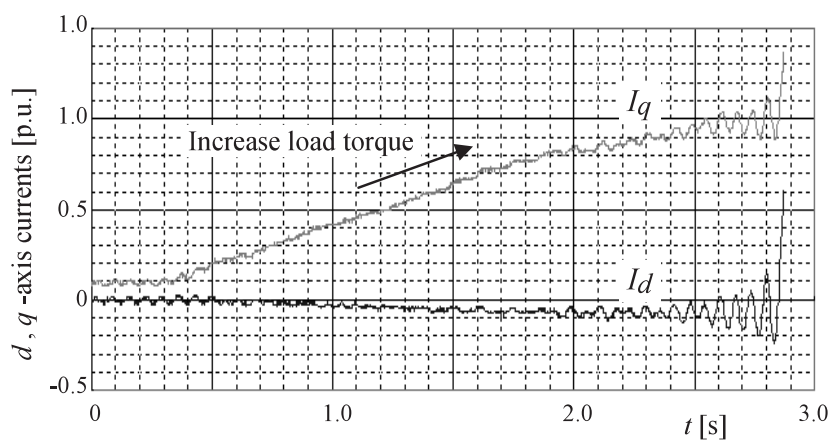

Fig. 11. An experiment result of unstable phenomenon.

$\langle\mathbf{5} \cdot \mathbf{2}\rangle$ 試験結果＼cjkstart速度制御モードにおいて，モデル インダクタンス $L^{*}$ に定格時の值 $\left(L_{q}=0.60 \mathrm{mH}\right)$ をまた

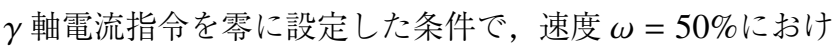
る安定限界を計測した結果が Fig. 11 である。位置センサ を基準とする $d-q$ 軸の電流波形を観測しながら，脱調する まで軽負荷状態から負荷を徐々に増加させた。負荷の増加 とともに $q$ 軸電流が増加するが，あるレベルに達すると振 動が発生し, その直後に脱調した。 $\gamma$ 軸電流指令の設定を 変更して Fig. 11 と同様の試験を繰り返して行い, 計測した $d$ 軸と $q$ 軸の電流を $d-q$ 軸の電流座標上の軌跡として表し たものが Fig. 12 である。(a) 図はモデルインダクタンスを $L^{*}=0.60 \mathrm{mH}$ に設定した場合であり, (b) 図は $L^{*}=0.43 \mathrm{mH}$ のように小さく設定した場合である。

脱調直前に発生する振動の中心を結んだ包絡線が安定限 界であるとみなして点線で示した。Fig. 13 は Fig. 12 と同 様の試験を速度 $\omega=75 \%$ で実施したものである。

FEM 解析結果である Fig. 6 および Fig. 9 の位相誤差 $\Delta \theta=0^{\circ}$ の等高線よりも実際の安定領域が狭く, $\Delta \theta$ がま た正の領域から電流の振動が発生している。このことか $ら\langle 4 \cdot 1\rangle$ 節の位相誤差 $\Delta \theta$ に起因する定常時の安定限界よ り,$\langle 4 \cdot 2\rangle$ 節の位相誤差の変化分 $\Delta \theta^{\prime}$ による外乱電圧の 影響の方が支配的であると考えられる。また，安定限界線 はFig. 3 で示した電圧の等高線と似た形状をしていること から，(16) 式で示した二種類の外乱成分のうち電圧の影響 の方が大きいものと考えられる。速度が高くなると安定領 域が狭くなるのは, 永久磁石や電機子反作用磁束による速 度起電力の増加により, 干渉電圧成分も増加したと考えら

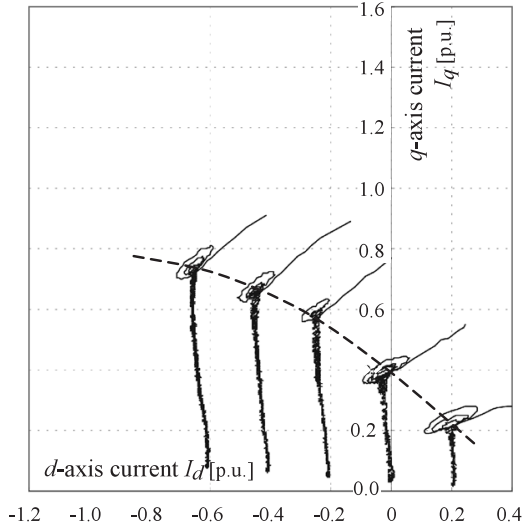

(a) $L^{*}=0.60 \mathrm{mH}, \omega=50 \%$

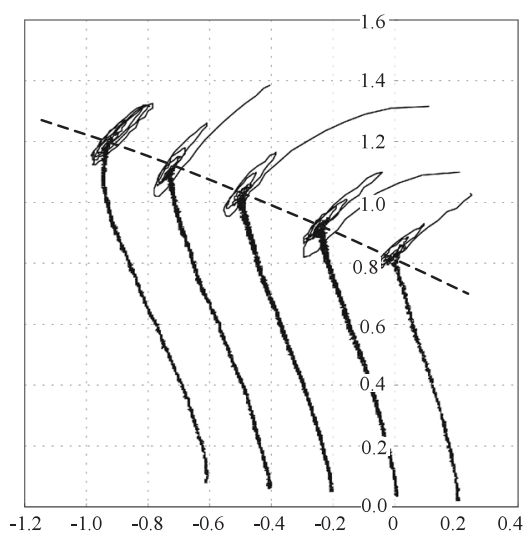

(b) $L^{*}=0.43 \mathrm{mH}, \omega=50 \%$

Fig. 12. Characteristics of unstable region $(\omega=50 \%)$.

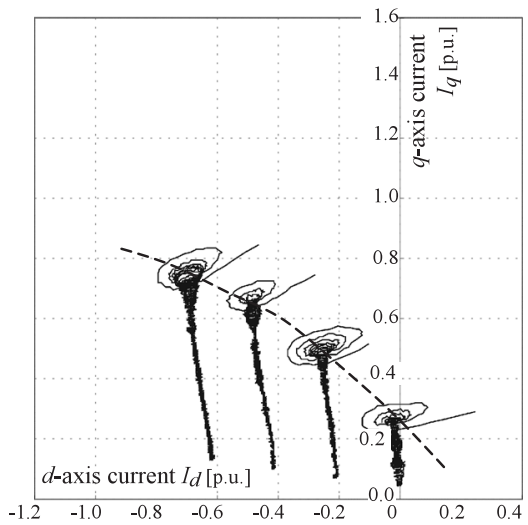

(a) $L^{*}=0.60 \mathrm{mH}, \omega=75 \%$

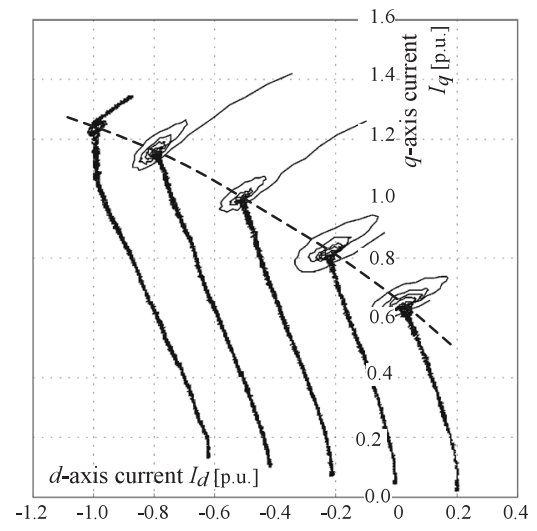

(b) $L^{*}=0.43 \mathrm{mH}, \omega=75 \%$

Fig. 13. Characteristics of unstable region $(\omega=75 \%)$. 
れる。このように，二種類の外乱電圧成分が要因であると いう推定と実験結果は符合しており，また〈4·3〉節で述べ たようにモデルインダクタンスの設定值を小さくすると (b) 図のように安定領域が拡大できることも確認できた。

実験結果の安定状態における電流軌跡も，計算した Fig. 7 や Fig. 9 の実電流の軌跡と同様な傾きを有しており， 〈4・1〉節で説明した定常時の収束条件が妥当であることも 確認できた。Fig.9の計算值よりも Fig. 12(b) の実験結果の 電流軌跡の方が $10^{\circ} \sim 15^{\circ}$ 程度傾いているが，これは FEM 解析と実モー夕に使用した鉄心の磁気特性の差によるもの と想定している。

\section{6. あとがき}

磁気飽和のある IPMSM に磁束オブザーバを使用したセ ンサレス制御を適用した場合には，不安定領域が存在する ことを示した。誘導機の場合にも磁気飽和による励磁イン ダクタンスの変動が存在するが，すべり誤差になるだけで 脱調することはない。すなわち，この脱調現象は PMSM 特 有の現象であるといえる。

この原因について FEM 解析を用いて検討し，推定位相 誤差の変化成分により軸間の干渉電圧に相当する影響が存 在すること，およびモデルインダクタンスの設定值を小さ くすることにより安定性が改善できることを示した。

この現象はモー夕の非線形性が原因であるため，最小次 元オブザーバや拡張誘起電圧などの方法を利用した場合で も同じ現象が発生する。つまり，今回の検討内容はこれら の制御方式の場合でも有効である。

(平成 19 年 1 月 29 日受付，平成 19 年 6 月 30 日再受付)

\section{文献}

(1) G. Yang, R. Tomioka, M. Nakano, and T.H. Chin: "Position and Speed Sensorless Control of Brushless DC Motor Based on an Adaptive Observer", $T$. IEE Japan, Vol.113-D, No.5, pp.579-586 (1993-5) (in Japanese)

楊耕・富岡真知子・中野 求・金 東海:「適応オブザーバによ るブラシレス DC モータの位置センサレス制御」, 電学論 D, 113, 5 , pp.579-586 (1993-5)

(2) K. Hirano, H. Hara, T. Tsuji, and R. Oguro: "Sensorless Speed Control of IPM Motor", T. IEE Japan, Vol.120-D, No.5, pp.666-672 (2000-5) (in Japanese

平野孝一・原 英博 - 辻 輝生・小黒龍一：「IPM モー夕のセンサ レス速度制御」, 電学論 D, 120, 5, pp.666-672 (2000-5)

(3) S. Shinnaka: "New Sensorless Vector Control Methods Based on a New Minimum-Order Flux Stage-Observer in the "D-Module" for Permanent Magnet Synchronous Motors", T. IEE Japan, Vol.123-D, No.12, pp.14461460 (2003-12) (in Japanese)

新中新二：「永久磁石同期モータの最小次元 $\mathrm{D}$ 因子状態オブザーバ とこれを用いたセンサレスベクトル制御法の提案」, 電学論 D, 123, 12, pp.1446-1460 (2003-12)

(4) S. Ichikawa, Z. Chen, M. Tomita, S. Doki, and S. Okuma: "Sensorless Control of Salient-Pole Permanent Magnet Synchronous Motors Using Extended Electromotive Force Models", T. IEE Japan, Vol.122-D, No.2, pp.1088-1094 (2002-2) (in Japanese)

市川慎士・陳 志謙 ・冨田睦雄・道木慎二・大熊 繁：「拡張誘起電 圧モデルに基づく突極形永久磁石同期モータのセンサレス制御」, 電 学論 D, 122, 2, pp.1088-1094 (2002-2)

( 5 ) Y. Yamamoto, Y. Yoshida, and T. Ashikaga: "Sensor-less Control of PM Motor using Full Order Flux Observer", T. IEE Japan, Vol.124-D, No.8, pp.743-749 (2004-8) (in Japanese)
山本康弘・吉田康宏・足利 正：「同一次元磁束オブザーバによる PM モータのセンサレス制御」, 電学論 D, 124, 8, pp.743-749 (2004-8)

(6) H. Kato, S. Doki, and M. Ishida: "q-axis Inductance Setting Method for SynRM's Sensorless Control with An Extended Electromotive Force", the 2005 Japan Industry Applications Society Conference, I-104, pp.383-384 (2005) (in Japanese)

加藤寛基・道木慎二 ·石田宗秋：「拡張誘起電圧を用いた SynRMに おけるセンサレス制御のための $\mathrm{q}$ 軸インダクタンス設定法」, 平 17 年電気学会産業応用部門大会, I-104, pp.383-384 (2005)

(7) S. Shinnaka and K. Sano: "Convergence Characteristics of D-Sate-Observer Using Nominal Motor Parameters with Errors for Sensorless Drive of Permanent-Magnet Synchronous Motors", the 2006 Japan Industry Applications Society Conference, I-66, pp.399-400 (2006) (in Japanese) 新中新二・佐野公亮：「永久磁石同期モータセンサレス駆動のため の D 因子状態オブザーバのパラメー夕誤差に対する収束特性」, 平 18 年電気学会産業応用部門大会, I-66, pp.399-340 (2006)

(8) Y. Yamamoto, Y. Yoshida, Y. Higashi, and H. Matsuno: "Measurement of Unstable Region of PM Sensorless Control", the 2006 Japan Industry Applications Society Conference, I-105, pp.529-532 (2006) (in Japanese) 山本康弘・吉田康宏・東 義高・松野浩晃：「PM センサレス制御 の不安定領域の計測」, 平 18 年電気学会産業応用部門大会, I-105, pp.529-532 (2006)

山 本 康 弘 (正員) 1958 年 7 月 8 日生。 1983 年 3 月長岡技

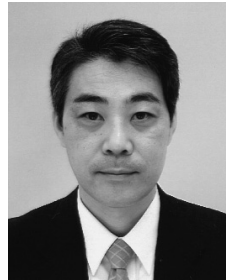
術科学大学大学院電気電子システム工学専攻修士 課程修了。同年 4 月（株）明電舎入社。現在，誘 導機のベクトル制御および PM モータの可変速駆 動装置の研究に従事。2006 年 10 月宇都宮大学博 士後期課程に入学。

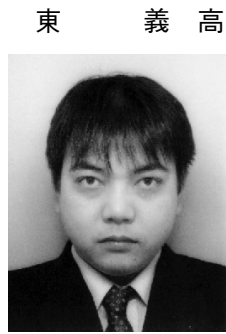

（正員） 1973 年 2 月 7 日生。 1997 年 3 月鹿児島 大学大学院工学研究科電気電子工学専攻修士課程 修了。同年 4 月（株）明電舍入社。現在，永久磁 石界磁形同期電動機の開発・設計に従事。

松 野 浩 晃 (正員) 1977 年 2 月 10 日生。 2001 年 3 月岐阜

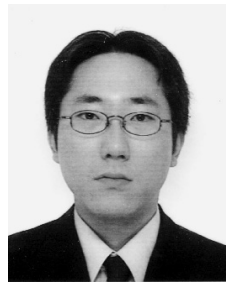
大学大学院博士前期課程修了。同年 4 月（株）明 電舎入社。現在，(株) 甲府明電舎に扔いて，誘 導機掞よび永久磁石界磁形同期機の開発・設計に 従事。

小笠原 悟 司（正員） 1958 年 7 月 27 日生。1981 年 3 月長岡

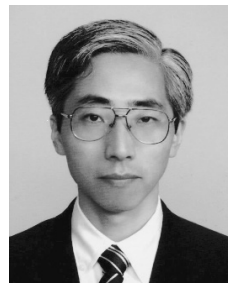
技術科学大学工学部電気・電子システム工学課程 卒業, 1983 年 3 月長岡技術科学大学大学院電気 電子システム工学専攻修士課程修了。同年 4 月同 大学工学部電気系助手, 1992 年 8 月岡山大学工 学部電気電子工学科助手, 1993 年 4 月同助教授, 2003 年 4 月宇都宮大学工学部電気電子工学科教 授，2007 年 4 月北海道大学大学院情報科学研究 科教授，現在に至る。工学博士。 